\title{
IDENTIFIKASI POTENSI BAHAYA DAN PENGENDALIANNYA PADA PEKERJAAN BEKISTING ALUMA SYSTEM PROYEK X
}

\author{
Kusumo Dradjad Sutjahjo ${ }^{\circledR}$, Tri Wulan Sari ${ }^{\bowtie 2}$, Fadhlina Sahara ${ }^{3}$ \\ ${ }^{1}$ Jurusan Teknik Sipil, Politeknik Negeri Jakarta, JL. Prof DR. G.A. Siwabessy, Kampus Universitas \\ Indonesia, Depok, 16425 \\ kusumo.drajadsutjahjo@sipil.pnj.ac.id ${ }^{\bigotimes 1}$, tri.wulansari@sipil.pnj.ac.id四2 \\ Fadhlina.sahara.ts17@pnj.ac.id ${ }^{3}$,
}

\begin{abstract}
Work at height is a job with a high risk of accidents, such as in the formwork aluma system. Weak supervision and a lack of knowledge of the workforce on potential hazards and risk control of the formwork aluma system are some of the causes of the high incidence of work accidents in this work. This research was conducted on the formwork aluma system of the BRI Gatot Subroto tower project, South Jakarta. The goal is to determine the potential hazards and risk control of aluma system formwork. Risk analysis is carried out using the AS / NZS 4360: 2004 standard to determine the level of risk to the potential hazards of the aluma system formwork. Potential hazards in the formwork aluma system are falling, bumping, being cut, punctured and crushed, with the level of risk being at high, substantial, medium and low levels. Risk control is carried out by the control hierarchy, namely elimination, substitution, engineering, administration, and control of PPE.
\end{abstract}

Keywords: AS / NZS 4360: 2004, Risk Analysis, Hazards, Aluma System Formwork.

\begin{abstract}
ABSTRAK
Pekerjaan di ketinggian merupakan pekerjaan yang memiliki risiko kecelakaan yang tinggi seperti pada pekerjaan bekisting aluma system. Pengawasan yang lemah dan kurangnya pengetahuan tenaga kerja terhadap potensi bahaya serta pengendalian risiko pekerjaan bekisting aluma system merupakan salah satu penyebab tingginya kecelakaan kerja pada pekerjaan ini. Penelitian ini dilakukan pada pekerjaan bekisting aluma system proyek menara BRI Gatot Subroto, Jakarta Selatan. Tujuan penelitian ini untuk melakukan identifikasi potensi bahaya dan pengendalian risiko pekerjaan bekisting aluma system. Analisa risiko dilakukan dengan menggunakan standart AS/NZS 4360:2004 yaitu penilaian risiko dengan parameter probability, exposure dan consequence. Tingkat risiko didapat dengan hasil perkalian dari tiga parameter tersebut. Berdasarkan hasil penelitian, potensi bahaya pada pekerjaan bekisting aluma system yaitu: terjatuh, terbentur, terpotong, tertusuk dan tertimpa, dengan tingkat risiko berada pada tingkat tinggi, substansial, menengah dan rendah. Pengendalian risiko dilakukan sesuai dengan hirarkhi pengendalian yaitu eliminasi, subtitusi, engineering, administrasi dan pengendalian APD.
\end{abstract}

Kata Kunci : AS/NZS 4360:2004, Analisa Risiko, Bahaya, Bekisting Aluma System.

\section{PENDAHULUAN}

Banyaknya kecelakaan kerja di ketinggian khususnya pekerjaan bekisting aluma system, lemahnya pengawasan dan kurangnya pengetahuan tenaga kerja terhadap potensi bahaya dan pengendalian risiko pekerjaan bekisting aluma system merupakan salah satu penyebab terjadinya kecelakaan kerja. Bekisting aluma system masih tergolong baru sehingga belum banyak proyek yang menggunakan bekisting tipe alform, penelitian terdahulu mengenai analisa risiko pekerjaan bekisting di ketinggian merupakan acuan dalam membuat penelitian tentang potensi bahaya dan pengendalian risiko pekerjaan bekisting aluma system [1].

Tujuan dalam penelitian ini adalah untuk menganalisa potensi bahaya pada pekerjaan bekisting aluma system dan 
mengetahui pengendalian risiko terhadap potensi bahaya yang terjadi. Penelitian ini fokus pada pekerjaan bekisting aluma system periode pekerjaan bulan Februari-Maret 2020 dan meninjau sumber daya manusia, sumber daya alat dan bahan dan metode kerja.

Bekisting aluma system merupakan bekisting khusus yang berbahan dasar alumunium mutu tinggi, ringan dan kuat. Bekisting ini merupakan salah satu inovasi dalam metode pekerjaan bekisting. Kelebihan bekisting aluma system yaitu efektif dan efisien baik dalam segi biaya, mutu dan waktu pekerjaan. Ruang lingkup pekerjaan bekisting aluma system meliputi pabrikasi bekisting, pengangkatan bekisting, pemasangan dan setting bekisting dan pembongkaran bekisting [1].

Potensi bahaya adalah kondisi atau keadaan baik pada manusia, peralatan, mesin, pesawat angkut, metode kerja, bahan, dan lingkungan yang berpotensi menimbulkan gangguan, kerusakan, kerugian, kecelakaan, dan penyakit akibat kerja [2]. Sumber bahaya umumnya berasal dari sumber daya manusia, sumber daya alat dan bahan, metode kerja, dan lingkungan kerja. Bahaya juga dipengaruhi oleh jenis faktor bahaya seperti bahaya mekanis, kimia, biologis, fisik, ergonomik dan psikologis [3]. Potensi bahaya pada pekerjaan bekisting aluma system yaitu tertusuk saat sedang merakit elemen truss, terjepit baut, tersandung material besi yang berserakan. Proses pengangkatan memiliki potensi bahaya pekerja terjatuh dan tertimpa material akibat sling TC yang putus. Tahapan pemasangan dan setting bekisting aluma system berpotensi bahaya terjatuh dari ketinggian, tertusuk, dan tertimpa [4].

Risiko diidentifikasi sebagai kombinasi kemungkinan dari suatu peristiwa dan konsekuensi. Risiko dapat diukur dan diatur dengan faktor acuan yaitu seberapa sering bahaya itu muncul dan seberapa parah jika terjadi kecelakaan [5]. Faktor risiko yang dapat memperbesar risiko antara lain [6]:

1. jarak waktu/jangka waktu.

2. keterbatasan informasi.

3 . keterbatasan pengetahuan.

Menggunakan standart AS/NZS 4360:2004 dalam penilaian risiko dengan parameter peluang, paparan, dan akibat [7]. Tingkat risiko didapat dengan hasil perkalian dari tiga parameter tersebut. Analisa dan penilaian risiko dilakukan untuk menentukan tingkat risiko sehingga dapat menentukan pengendalian risiko yang tepat dari setiap tahapan pekerjaan bekisting aluma system.

Sesuai dengan UU No. 1 tahun 1970 tentang Keselamatan Kerja dan sesuai dengan PP No. 50 tahun 2012 tentang Sistem Manajemen Keselamatan dan Kesehatan Kerja menyatakan bahwa semua proyek konstruksi wajib menerapkan Sistem Manajemen Keselamatan dan Kesehatan Kerja serta didukung dengan PERMEN PU No. 21 Tahun 2019 tentang Pedoman Penerapan SMK3 bidang Pekerjaan Umum. Dengan menerapkan SMK3 pada proyek konstruksi bertujuan untuk menciptakan lingkungan kerja yang lebih aman, lancar, efektif, dan juga terbebas dari ancaman kecelakaan dan penyakit kerja.

Pengendalian risiko dilakukan dengan menekan probability, konsekuensi dan pengalihan risiko [8]. Pengendalian risiko dapat dilakukan dengan menekan probability menggunakan pendekatan eliminasi, subtitusi, administrasi dan pengendalian APD [9],[10]. 


\section{METODE PENELITIAN}

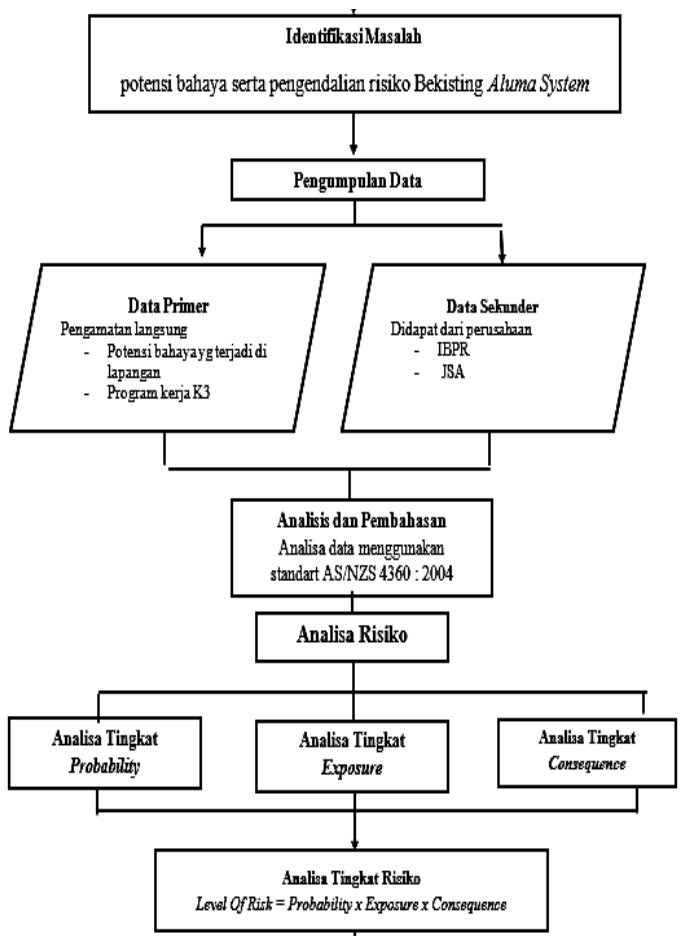

Gambar 1. Flowchart Penelitian

\section{Identifikasi Masalah}

Hasil dari kegiatan ini adalah dapat mengetahui macam-macam potensi bahaya dan cara pengendalian risiko dalam pelaksanaan pekerjaan Bekisting Aluma System.

\section{Pengumpulan Data}

Pada tahap ini informasi dikumpulkan berdasarkan objek permasalahan yang dibahas. Berikut adalah dua jenis data, yaitu:

a. Data Primer

Data primer adalah data yang diperoleh pada penelitian.

- Observasi Lapangan

Melakukan peninjauan langsung pada Proyek Menara BRI Gatot Subroto, Jakarta Selatan untuk mengumpulkan data berupa metode kerja bekisting Aluma System, SOP pekerjaan bekisting Aluma System, mengamati potensi bahaya yang dapat memicu kecelakaan dan disesuaikan dengan teori AS/NZS 4360 : 2004. b. Data Sekunder

Berikut data sekunder yang harus dikumpulkan/diminta dari perusahaan:

- IBPR Pekerjaan Bekisting Aluma System

- JSA Pekerjaan Bekisting Aluma System

\section{Analisis Data}

Analisis data dengan menggunakan metode analisis deskriptif semi kualitatif yang mengacu pada standar AS/NZS 4360: 2004 dimaksudkan untuk mengelompokan data berdasarkan variabel untuk analisis risiko dan pengendalian risiko yang disusun dalam bentuk tabel adapun variable yang digunakan yaitu bahaya, level risiko, dan cara pengendalian. Analisis data dilakukan setelah data primer dan data sekunder terkumpul. Data hasil analisis akan disajikan dalam bentuk tabel dan radar chart. Analisis potensi bahaya dapat ditentukan menggunakan data hasil observasi dan disajikan dalam bentuk radar chart.

Analisa Tingkat Risiko (Level of Risk) Penilaian risiko ditentukan setelah mendapatkan komponen nilai probability, exposure dan consequence. Untuk menentukan tingkat risiko, maka diperlukan perhitungan terhadap ketiga komponen tersebut. Berikut rumus untuk menghitung Level of Risk:

Level of Risk $=$ Probability $x$ Exposure $x$ Consequence

Berikut Kriteria tingkat risiko yang dapat dilihat pada Tabel 1, yaitu:

Tabel 1. Kriteria Tingkat Risiko

\begin{tabular}{cc}
\hline Tingkatan & Kategori \\
\hline$>400$ & Sangat Tinggi \\
$200-400$ & Tinggi \\
$70-200$ & Substansial \\
$20-70$ & Menengah \\
$<20$ & Rendah \\
\hline
\end{tabular}

Sumber : AS/NZS 4360 : 2004 Risk Management Guideline (2004) 
Analisis tingkat risiko ditinjau dari basic level dan existing level. Basic level dilakukan pada saat sebelum ada pengendalian serta risiko dilihat saat keadaan terburuk sedangkan existing level pada saat setelah adanya pengendalian.

Setelah melakukan analisis tingkat risiko, dilakukan risk reduction untuk melihat seberapa besar presentase yang didapat setelah dilakukannya pengendalian. Adapun rumus yang digunakan untuk mencari nilai risk reduction adalah:

Risk reduction $=\frac{\text { Basic Level }- \text { Existing Level }}{\text { Basic Level }}$ x $100 \%$

Setelah hasil risk reduction didapat, lalu dirata-rata, maka dikelompokan sebagai penilaian penerapan pengendalian sesuai dengan tabel berikut ini.

\begin{tabular}{ll}
\hline \multicolumn{1}{c}{ TINGKAT } & KETERANGAN \\
PENCAPAIAN & \\
\hline $0-59 \%$ & Tingkat penilaian \\
& kurang \\
$60-84 \%$ & Tingkat penilaian baik \\
$85-100 \%$ & Tingkat penilaian \\
& memuaskan \\
\hline
\end{tabular}

\section{HASIL dan PEMBAHASAN}

Identifikasi potensi bahaya dilakukan dengan observasi langsung dengan mempertimbangkan seluruh tahapan pekerjaan bekisting aluma system, kondisi dan kejadian yang berpotensi menimbulkan bahaya, serta form JSA.

Identifikasi bahaya pada penelitian ini dilakukan dengan observasi langsung dan berdasarkan selururuh proses kegiatan pekerjaan. Berdasarkan bahaya ekstrim hingga bahaya rendah. Identifikasi sumber bahaya dilakukan dengan mempertimbangkan:

- kondisi dan kejadian yang berpotensi menimbulkan bahaya

- jenis kecelakaan dan penyakit akibat kerja yang mungkin dapat terjadi.
- form Job Safety Analysis proyek Menara BRI Gatot Subroto.

Potensi bahaya pada seluruh tahapan pekerjaan bekisting aluma system yang secara lengkap terdapat pada Tabel 3 yaitu:

1. Sumber daya manusia: pekerja kurang kompeten, lalai, dan kehilangan konsentrasi sehingga menyebabkan celaka.

2. Sumber daya alat dan bahan: pekerja tertimpa material bekisting aluma, kulit iritasi akibat terpapar minyak bekisting yang menempel pada material besi.

3. Metode kerja: pekerja terjatuh akibat alat pelindung kerja yang sudah tidak layak pakai dan tidak tepat sasaran.

Potensi bahaya juga dipengaruhi oleh faktor bahaya seperti bahaya mekanis, fisik, kimia, biologis, ergonomik dan psikologis. Berikut ini radar chart yang menunjukan besar nya bahaya dari setiap sumber bahaya.

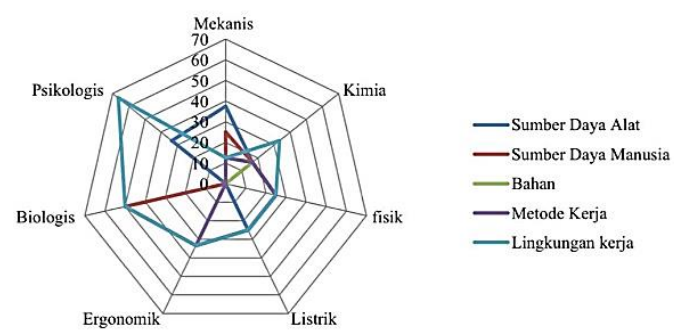

Gambar 2. Radar chart Analisa potensi bahaya pekerjaan bekisting aluma system

Berdasarkan radar chart analisa potensi bahaya pekerjaan bekisting Aluma System, adapun potensi bahaya yang terdapat pada seluruh pekerjaan bekisting aluma system terdiri dari:

- Sumber daya manusia yaitu pekerja kurang kompeten, lalai dan kehilangan konsentrasi sehingga menyebabkan tangan tertusuk,tergores, dan terjepit.

- Sumber daya alat dan bahan yaitu pekerja tertimpa material aluma truss, kulit iritasi karena terkena oli 
bekisting aluma yang menempel pada material aluma.

- Metode kerja yaitu pekerja terjatuh akibat life line yang tidak memadai.

- Lingkungan kerja yaitu material aluma berserakan membuat lingkungan tidak rapih dan berpotensi menimbulkan bahaya.

Radar chart menunjukan bahwa potensi bahaya yang terdapat pada pekerjaan Bekisting Aluma System Proyek Menara BRI Gatot Subroto juga terdiri dari faktor jenis bahaya yaitu dengan potensi bahaya yang ada pada pekerjaan di ketinggian khususnya pada pekerjaan bekisting aluma system, adapun pengendalian yang dilakukan dengan cara menekan probability dengan beberapa pendekatan, antara lain :

1. Eliminasi bahaya, yaitu dengan mengganti peralatan angkut manual menjadi alat angkut mekanik seperti penggunaan hoist builder dan tower crane.

2. Subtitusi, berupa penggantian alat, bahan dan proses operasi alat menjadi sistem otomatisasi.

3. Rekayasa Teknik (engineering), berupa pengadaan penutup mesin, circuit breaker, sistem ventilasi, safety net dan alat pelindung kerja lainnya.

4. Pengendalian Administrasi, dengan adanya rambu K3, pelatihan, SHE Patrol, JSA dan IBPR

5. APD, berupa pengadaan Full Body Harness bagi seluruh pekerja konstruksi, maupun karyawan kantor Proyek Menara BRI Gatot Subroto.

Radar chart analisa tingkat risiko menunjukan bahwa basic level memiliki tingkat risiko tinggi dan substansial karena belum adanya pengendalian dan diasumsikan keadaan terburuk, sedangkan pada existing level tingkat risiko berada pada tingkat menengah dan rendah, ini menunjukan bahwa dengan adanya pengendalian, dapat menurunkan tingkat risiko.

Ditinjau dari presentase Risk Reduction (penurunan risiko), memiliki rata-rata sebesar $87 \%$ ini menunjukan bahwa penerapan pengendalian tergolong memuaskan.

\section{KESIMPULAN}

Potensi bahaya pekerjaan bekisting aluma system terdiri dari sumber daya manusia berupa pekerja tidak kompeten, lalai dan kehilangan konsentrasi sehingga berpotensi menimbulkan celaka. Sumber daya alat dan bahan berupa tangan terpotong akibat gergaji yang tajam, kulit iritasi akibat terpapar minyak bekisting yang menempel pada besi aluma. Metode kerja berupa pekerja terjatuh dari ketinggian akibat alat pelindung kerja tidak layak dan penggunaan APD yang tidak tepat, pekerja tersandung akibat besi aluma yang berserakan. Pengendalian risiko terhadap potensi bahaya pekerjaan bekisting aluma system dilakukan sesuai dengan hirarkhi pengendalian yaitu eliminasi bahaya, subtitusi bahaya, engineering, administrasi, dan pengendalian APD.

\section{DAFTAR PUSTAKA}

[1] Work Method Structure Pekerjaan Bekisting Aluma Proyek Menara BRI Gatot Subroto, Jakarta Selatan (2020).

[2] Peraturan Mentei Pekerjaan Umum No. 21 Tahun 2019 Tentang Pedoman SMKK Bidang Pekerjaan Umum

[3] Dradjad, K. (2019). Buku Ajar Keselamatan dan Kesehatan Kerja 1. Jakarta

[4] Irawan, S., \& Beryladityanto. Manajemen Risiko K3 pada Pekerjaan Struktur Bawah dan 
Struktur Atas Gedung Bertingkat. 2019. Semarang

[5] Hutasoit, E.O., (2016). Analisa Rsiko Kecelakaan Kerja pada Proyek Pembangunan Jembatan. Surabaya.

[6] Nursin, A. (2005). Analisa Pelaksanaan Manajemen Risiko dalam Indsutri Konstruksi Studi Kasus pada Proyek PT. Adhi Karya. POLITEKNOLOGI Vol. 4 No. 1

[7] Standart AS/NZS 4360:2004 Risk Management Guideline
[8] Zaharani, T. (2018). Potensi Bahaya Pekerjaan Bekisting Aluma. Depok

[9] Anisah, Z. (2018). Pengendalian Risiko K3 pada Pekerjaan Pembesian pada Proyek Trans Park Cibubur. Depok .

[10] Shofiana, I. (2015). Identifikasi Potensi Bahaya Pekerjaan Ketinggian pada Proyek Gedung Parkir RS Telogorejo oleh PT. Adhi Karya.Semarang.

\section{Lampiran Tabel - Tabel}

Tabel 3. Data Hasil Observasi : Data Potensi Bahaya Pekerjaan Bekisting Aluma System.

\begin{tabular}{|c|c|}
\hline Potensi Bahaya Mekanis & Sumber Bahaya \\
\hline Tangan Terpotong akibat Mata Gergaji Tajam & Alat \\
\hline Kaki tertimpa besi aluma & Bahan \\
\hline Tangan tertusuk paku karena pekerja tidak focus melihat & Manusia \\
\hline Terjepit aluma truss & Alat \\
\hline Terjatuh dari scaffolding saat merakit di ketinggian karena kelalaian pekerja & Manusia \\
\hline Tertimpa aluma beam karena sling TC putus saat mengangkut & Alat \\
\hline Pekerja kejatuhan material aluma karena scaffolding kelebihan muatan & Metode Kerja \\
\hline Pekerja Tersandung scaffolding yang berserakan disekitar lokasi perakitan & Lingkungan \\
\hline Potensi Bahaya Kimia & Sumber Bahaya \\
\hline Pekerja kurang kompeten dan lalai terhadap bahan kimia & Manusia \\
\hline Pekerja menghirup debu disekitar lokasi pekerjaan & Lingkungan \\
\hline Mata kemasukan debu kotoran & Lingkungan \\
\hline $\begin{array}{l}\text { Kulit iritasi karena terkena oli bekisting aluma yang menempel pada material } \\
\text { aluma }\end{array}$ & Alat dan Bahan \\
\hline Pekerja tergelisir akibat penempatan oli bekisting yang kurang tepat & Metode Kerja \\
\hline Pekerja sulit bernapas akibat polusi udara & Lingkungan \\
\hline Potensi Bahaya Fisik & Sumber Bahaya \\
\hline Pekerja dapat celaka akibat kehilangan konsentrasi karena suhu ekstrim & Manusia \\
\hline Pekerja terkena gangguan pendengaran akibat terpapar suara bising peralatan kerja & Alat \\
\hline Pekerja tergelincir akibat kurang pencahayaan & Lingkungan \\
\hline Pekerja terkena gangguan saraf akibat terpapar getaran & Metode Kerja \\
\hline Potensi Bahaya Ergonomik & Sumber Bahaya \\
\hline $\begin{array}{l}\text { Sikap jongkok saat melakukan perakitan dan pabrikasi bekisting yang } \\
\text { membutuhkan waktu }\end{array}$ & Metode \\
\hline Gerakan bolak balik mengangkut besi material & Manusia \\
\hline Buruk nya desain lokasi kerja & Lingkungan \\
\hline Potensi Bahaya Biologi & Sumber Bahaya \\
\hline Terinfeksi mikroorganisme yang berasal dari tumpukan sampah di area kerja & Lingkungan \\
\hline Pekerja terinfeksi bakteri karena tidak memperhatikan kebersihan makanan & Manusia \\
\hline Potensi Bahaya Listrik & Sumber Bahaya \\
\hline $\begin{array}{l}\text { Tersetrum arus pendek listrik yang berasal dari peralatan mesin yang berkaitan } \\
\text { dengan pekerjaan bekisting }\end{array}$ & Alat \\
\hline Pekerja tersandung kabel listrik kompressor yang berantakan di area kerja & Lingkungan \\
\hline Pekerja terjatuh dari ketinggian akibat tersengat arus pendek & Metode \\
\hline Pekerja kurang konsentrasi & Manusia \\
\hline
\end{tabular}


Beban pikiran karena tanggung jawab yang besar

Kesenjangan antar pekerja yang mempengaruhi pikiran saat bekerja sehingga tidak fokus dan menyebabkan kemungkinan kecelakaan.

Tabel 4. Faktor Jenis Bahaya

\begin{tabular}{cl}
\hline Jenis Bahaya & \multicolumn{1}{c}{ Uraian } \\
\hline Mekanis & Mata gergaji yang tajam, berpotensi tangan terpotong \\
Kimia & Paparan bahan kimia seperti minyak bekisting dapat membuat kulit iritasi \\
Fisik & Kurangnya pencahayaan, berpotensi terjatuh \\
Biologis & Infeksi bakteri/virus, dapat berpotensi bahaya gangguan kesehatan \\
Ergonomik dan & Gerakan berulang dan tekanan kerja yang tinggi. \\
Psikologis & \\
\hline
\end{tabular}

